\title{
8 \\ BAHASA DAKWAH PEMERINTAH MEMBANGUN HARMONISASI KEBANGSAAN
}

\author{
Farhan \\ Universitas Nurul Jadid Probolinggo \\ farhan.alim11@gmail.com
}

\begin{abstract}
This paper examines the reality of Da'wa language in the interaction and communication to the head of state with the peoples. The diversity of tribes, religions, races, and groups within the archipelago needs to be handled wisely, so that the harmonization of citizens continues to be strengthened in all aspects of life. Uploading the message of the head of state on you tube social media can be the right media to parse central and regional policies. You tube social media is a trend of millennial society that is loved by all groups. Therefore, the head of state also needs to upload the existing social media. The message of the head of state needs to be known to all its people, both delivered during state speeches and in remarks on non-state activities. The President is the icon of a country, the national cultural identity of natural resources and human resources must be fully considered. It concerns state policies based on idealized ideals and constitutional grounds. All policies must be understood by the government apparatus from the central to the regions, officials to the people. However, the language of the head of state is not as easy as the educator explains it to students, the head of state needs high social sensitivity, so there is no obstacle means understanding all the messages he conveys. The head of state must provide an optimal and perfect example as a manifesto of the characteristics of Indonesian human resources as a whole. How are the messages of the head of state uploaded on social media 'You Tube'?. The head of state must provide an optimal and perfect example as a manifesto of the characteristics of Indonesian human resources as a whole. This study is a descriptive qualitative methode, the material from the cyber media, and analysis of the speechs of Ir. Joko Widodo in YouTube media from January to December 2017. The research shows that the president's verbal and nonverbal messages reflected the balance of communication between leaders and the people interactively; the meaning is humanist, religious, humorous, traditionalist, and nationalist. The analysis too shows that the head of the central government until the region must be a communicator, innovator and initiator wholeheartedly dealing with the interests of civil society in the millennial era, guarding the strengthening of national identity and religious ideology.
\end{abstract}

Keywords; Da'wa, Authority, Harmonization

Abstrak: Tulisan ini mengkaji realitas bahasa dakwah dalam interaksi dan komunikasi
kepala negara terhadap rakyat. Keberagaman suku, agama, ras, antargolongan di
nusantara perlu disikapi secara bijak, agar harmonisasi warganegara terus terjalin
semakin kuat dalam Semua aspek kehidupan. Pengunggahan pesan kepala negara di
media sosial you tube bisa menjadi media yang tepat mengurai kebijakan-kebijakan
pusat hingga ke daerah. Media sosial you tube merupakan tren masyarakat milenial
yang di gemari semua kalangan. Karena itu, kepala negara pun perlu melakukan
pengunggahan di media-media sosial yang ada. Pesan kepala negara perlu diketahui 
seluruh rakyatnya, baik disampaikan pada saat pidato kenegaraan maupun dalam sambutan-sambutan kegiatan non kenegaraan. Presiden adalah ikon sebuah negara, identitas budaya nasional sumber daya alam dan sumber daya manusia harus diperhatikan dengan sepenuhnya. Hal itu menyangkut kebijakan-kebijakan negara berpedoman landasan ideal maupun landasan konstitusional. Semua kebijakan harus dipahami aparatur pemerintah dari pusat hingga ke daerah, kalangan pejabat sampai rakyat. Namun, bahasa kepala negara tidak semudah semudah pendidik menjelaskannya kepada peserta didik, kepala negara membutuhkan kepekaan sosial yang tinggi, sehingga tidak ada kendala berarti memahami semua pesan yang disampaikannya. Kepala negara harus memberikan keteladanan optimal dan paripurna sebagai manifesto karakteristik sumber daya manusia Indonesia seutuhnya. Bagaimana pesan-pesan kepala negara yang diunggah di media sosial you tube? Melalui penelitian kualitatif deskriptif, dengan analisis media siber pada pidato Ir. Joko Widodo di media YouTube kurun Januari sampai Desember 2017, tulisan ini menyatakan bahwa pesan verbal dan non-verbal presiden merefleksikan keseimbangan komunikasi pemimpin dengan rakyat secara interaktif interkonektif; bermakna humanis, agamis, humoris, tradisionalis, dan nasionalis. Hasil analisis juga menyatakan bahwa kepala pemerintah pusat sampai daerah harus menjadi komunikator, inovator dan inisiator sepenuh hati berhadapan dengan kepentingan masyarakat sipil era milenial, mengawal penguatan Identitas nasional dan ideologi agama melalui bahasa dakwah universial.

Kata Kunci: Dakwah, Kekuasaan, Harmonisasi

\section{A. Pendahuluan}

Setiap pemerintah menghendaki rakyatnya hidup sejahtera dan menjalani kehidupan bermasyarakat yang rukun dan harmonis. Indonesia dengan semua kekayaan alam dan sumber daya manusia memiliki potensi luar biasa di Asia Tenggara sebagai negara yang pernah mengalami kejayaan masa lalu. Kepala negara merupakan representasi realitas masyarakat luas yang dipimpinnya. Semakin bijak kepala negara, maka semakin kuat jalinan komunikasi dan interaksi rakyat dan kepala negara.

Mengatur negara tidak semudah mengatur rumah tangga, dimana adanya ayah, ibu dan anak-anak menjadi satu kesatuan yang tidak dapat dipisahkan. Bila terjadi konflik antara anggota keluarga, maka ayah sebagai kepala keluarga memiliki peran dan andil besar dalam penyelesaiannya. Jaminan keharmonisan kehidupan anggota keluarga berada dalam dominasi sang ayah.

Presiden Republik Indonesia ke-7, Joko Widodo memiliki peranan cukup signifikan dalam memajukan dan memakmurkan seluruh lapisan masyarakat dalam semua aspek kehidupan. Jalinan komunikasi dan interaksi yang dibangun pemerintah kepada rakyat bukan hanya sekedar bahasa-bahasa konstruktif dalam mewujudkan cita-cita keadilan sosial bagi seluruh rakyat Indonesia. Melainkan harus didukung dengan berbagai upaya dan bukti nyata yang bisa dirasakan seluruh rakyat menerima kebijakan pemerintah yang sedang berkuasa. Meskipun tidak dapat dipungkiri adanya hambatan dan kendala dalam merealisasikan segala program yang telah diagendakan.

Kecerdasan dan kepekaan kepala negara dalam menentukan gaya kepemimpinan dan pilihan bahasa komunikasi dalam bidang politik menjadi indikator keberhasilan program yang direalisasikan. Semakin pandai kepala negara memahamkan semua lapisan, maka realisasi terhadap program semakin mencapai titik keberhasilan. Bahasa politik menjadi pilihan yang cukup rumit karena memiliki bias ambigu, terutama bagi oposisi. Namun setidaknya, dalam bahasa politik tiga ciri perlu dipahami; (1) politik berkaitan dengan pengaturan masyarakat banyak, bahasa politik menjadi alat komunikasi yang menjangkau seluruh lapisan masyarakat, 
(2) bertujuan membujuk dan merayu khalayak, dan (3) bahasa politik penuh dengan semboyansemboyan dan kata-kata bersayap seraya menghindari penggunaan bahasa yang berkonotasi netral dan objektif. 179

Perkembangan paradigma masyarakat sipil semakin maju seiring dengan penggunaan alatalat komunikasi yang dipergunakan. Media penyampaian pesan bisa dilakukan oleh siapa saja untuk memberikan pengaruh bagi penonton atau pembaca. Kehadiran media sosial cukup menarik perhatian para pemangku kebijakan untuk memahamkan semua kebijakan yang perlu segera diketahui oleh pihak-pihak terkait. Tidak terkecuali pemerintah dengan pemilihan mediamedia yang digunakan sebagai sosialisasi program presiden agar mudah dipahami rakyat.

Presiden Joko Widodo akan terus menjadi perhatian para wartawan. Hampir segala kegiatan yang dilakukan tidak bisa dilepaskan dari pemberitaan media massa. Media massa atas dasar ketokohan menjadi bahan berita yang selalu menarik untuk di up to date. Sehingga, semua pernyataan yang bersumber dari presiden tetap relevan diulas secara berkesinambungan karena berkaitan dengan pemangku kebijakan dalam semua aspek.

Dalam menyampaikan program pemerintah berbagai media dan metode dipergunakan agar pesan tersampaikan kepada semua lapisan masyarakat, tak terkecuali masyarakat di pedalaman atau pedesaan. Pemilihan media massa you tube cukup efektif dan efisien menarik perhatian para netizen (pengguna internet berjejaring) untuk memberikan pemahaman intens terhadap pesan kepala negara melalui kegiatan terdokumentasi. Hemat penulis, presiden Jokowi dengan karakter individu yang lama berpengalaman sebagai kepala (walikota, gubernur) memiliki kelebihan luar biasa. Berbeda dengan karakteristik presiden-presiden Republik Indonesia sebelumnya. Karena itu, penulis mencoba menguraikan bahasa dakwah Pemerintah membangun harmonisasi kebangsaan.

Dalam pemberitaas masing-masing media massa memiliki ideologi dan visi misi tersendiri. Penelitian Gallant dan Wahyudi mengungkapkan pembentukan citra publik pada harian suara merdeka, tabloid tempo dan harian Republika tentang Joko Widodo. Pemberitaan selama November 2015 hingga Januari 2016 dua media menunjukkan pembentukan citra positif, 51, 35 \% oleh Harian Suara Merdeka dan 58, 3 \% oleh Harian Republika, sedangkan Tabloid Tempo lebih cenderung pencitraan negatif $(66,67 \%) .{ }^{180}$ Pemberitaan tersebut wajar, dalam bahasa Eriyanto, setiap media memiliki ideologi media sendiri. ${ }^{181}$

Dalam satu tahun pemerintahan Jokowi tepat pada 20 Oktober 2015, indikator keberhasilan pemerintah termanifestasikan kedalam program nawacita. Pemberitaan di lima media massa dalam menunjukkan objektivitas dan imparsialitas pemberitaan terkait kinerja Joko Widodo dan Jusuf Kalla. ${ }^{182}$ Begitu pula program kedelapan nawacita 'revolusi mental' berkaitan dengan keterbukaan informasi publik berkualitas. ${ }^{183}$

Sembilan poin dalam nawacita; (1) Menghadirkan kembali negara untuk melindungi segenap bangsa dan memberikan rasa aman pada seluruh warga negara; (2) Membuat pemerintah tidak absen dengan membangun tata kelola pemerintahan yang bersih, efektif, demokratis, dan terpercaya; (3) Membangun Indonesia dari pinggiran dengan memperkuat daerah-daerah dan desa dalam kerangka negara kesatuan; (4) Menolak negara lemah dengan melakukan reformasi sistem dan penegakan hukum yang bebas korupsi, bermartabat, dan terpercaya; (5) Meningkatkan kualitas hidup manusia Indonesia melalui peningkatan kualitas

${ }^{179}$ Anwar, Fungi dan peranan Bahasa sebuah pengantar (Yogyakarta: Gajdah Mada University Press, 1984), 19.

180 Gallant Karunia Assidik dan B. Wahyudi Joko Santoso, Citra Publik Presiden Republik Indonesia Pada Pemberitaan Harian Suara Merdeka, Tabloid Tempo dan Harian Republika: Analisis Wacana Kritis Model Norman Fairclough, Seloka: Jurnal Pendidikan Bahasa dan Sastra Indonesia, 5 (2) 2016, 201-215.

181 Eriyanto, Analisis Framing Konstruksi, Ideologi, dan Politik Media (Yogyakarta: LkiS, 2004),

${ }^{182}$ Wulandari, Theresia. "Pemerintahan Jokowi-Jusuf Kalla Menurut Kacamata 5 Media Massa di Indonesia" Jurnal ASPIKOM [Online], Volume 3 Number 1 (18 July 2016), 88.

183 Dirgahayu, Dida, and Sunarsi, Risa. "Kontribusi Media Televisi Lokal dalam Menyosialisasikan Program Revolusi Mental" Jurnal Penelitian Komunikasi [Online], Volume 20 Number 2 (18 December 2017), 175. 
pendidikan dan pelatihan dengan program "Indonesia Pintar"; (6) Meningkatkan produktivitas rakyat dan daya saing di pasar internasional sehingga bangsa Indonesia bisa maju dan bangkit bersama bangsa-bangsa Asia lainnya; (7) Mewujudkan kemandirian ekonomi dengan menggerakkan sektor-sektor strategis ekonomi domestik; (8) Melakukan revolusi karakter bangsa melalui kebijakan penataan kembali kurikulum pendidikan nasional dengan mengedepankan aspek pendidikan kewarganegaraan, pengajaran sejarah pembentukan bangsa, nilai-nilai patriotisme dan cinta tanah air, semangat bela negara dan budi pekerti; (9) Memperteguh kebhinnekaan dan memperkuat restorasi sosial Indonesia melalui kebijakan memperkuat pendidikan kebhinnekaan dan menciptakan ruang-ruang dialog antarwarga. ${ }^{184}$

Presiden membumisasikan program-program dengan bahasa yang mudah dipahami. Hal itu tampak dalam setiap interaksinya dalam pidato kenegaraan dan acara lainnya. Nawacita yang memang telah dicita-citakan dan ditulis pada harian Kompas pada 10 Mei 2014 sejak sebelum jadi presiden tersebut merupakan konstruksi ideologi Joko Widodo sebagai kepala Negara. Selama menjabat sebagai presiden, bahasa-bahasa yang dipilih untuk menjelaskan semua citacita begitu merakyat, didukung dengan simbol-simbol komunikasi interaktif terutama dalam aspek pendidikan sebagai proses penting dalam pembentukan dan pengembangan karakter. 185 Karena itu, Joko Widodo seringkali menampilkan diri sebagai pendidik dihadapam publik dalam kegiatan-kegiatan tertentu. Tidak jarang presiden melontarkan humor yang sehat kepada rakyat.

Tampaknya presiden betul-betul menyadari pentingnya bahasa politik dalam penyampaian pesan penting. D. Nimmo dalam Suhaimi menyebut Dalam bidang politik, untuk memahami pesan politik perlu dilihat gejala linguistik bahasa dan simbol politik serta penggunaan bahasa untuk persuasi politik dalam wujud propaganda, periklanan maupun retorika. ${ }^{186}$

\section{B. Metode Penelitian}

Dalam kajian ilmu komunikasi berkembang istilah atau teori-teori berkaitan dengan wacana, semiotik dan lainnya yang kajian umumnya adalah teks media. ${ }^{187}$ Media massa terkini yang digandrungi masyarakat adalah media you tube dan atau audio visual. Karena itu, melalui kajian media siber peneliti mempergunakannya sebagai pengumpulan data. Metode penelitian yang digunakan yaitu metode analisis isi kualitatif dengan pendekatan deskriptif, yaitu untuk meneliti pada kondisi objek yang alamiah, menekankan pada isi dari suatu informasi baik berupa teks, gambar atau simbol. Dalam penelitian ini instrumennya adalah orang atau peneliti itu sendiri juga metode ini digunakan untuk mendapatkan data yang mendalam, suatu data yang mengandung makna.

\section{Hasil dan Diskusi}

Kajian tentang Presiden Jokowi sejak mencanangkan nawacita telah banyak dikaji. Ada dua hal yang menjadi item prioritas, yakni presiden sebagai sumber penyampai pesan dan presiden sebagai objek pesan dalam pemberitaan media. Media massa online seperti harian suara merdeka, Tabloid Tempo dan harian Republika merupakan bagian dari sekian media yang memberitakan Presiden Joko Widodo. Ketiganya memiliki karakteristik berbeda dalam

\footnotetext{
184 Nawacita gagasan pemerintah telah dibumisasikan oleh Presiden secara optimal untuk perubahan Indonesia berdaulat secara politik dan mandiri dalam ekonomi serta berkepribadian dalam kebudayaan. 185 Indriyanto, Bambang. "Mengkaji Revolusi Mental dalam Konteks Pendidikan" Jurnal Pendidikan dan Kebudayaan [Online], Volume 20 Number 4 (18 December 2014), 564.

186 Dan D. Nimmo, Komunikasi Politik Komunikator, Pesan dan Media, terj. Tjun Surjaman (Bandung: PT. Remaja Rosdakarya, 2004), 16.

${ }^{187}$ Asep Saeful Muhtadi, Komunikasi Politik Indonesia Dinamika Islam Politik Pasca Orde Baru (Bandung: PT Remaja Rosdakarya, 2008), iii.
} 
melakukan pemberitaan selama November 2015 hingga Januari 2016 menunjukkan pembentukan citra positif. 188

Dalam perayaan natal Nasional tahun 2016 di Gedung Wale Ne Tau, Tondano, Sulawesi Utara. ${ }^{189}$ Presiden Jokowi berinteraksi dengan seorang petani penuh canda tawa, utamanya pada saat petani asal Ranuwangkok terlihat gugup dalam membacakan Pancasila.

'Silahkan perkenalkan nama... (saya ingin lihat petani hafal Pancasila apa tidak'?' tanya presiden.Petani membacakan Pancasila, namun sila kedua petani lupa, lalu menyebut 'kerakyatan yang dipimpin...." disambut gelak tawa oleh penonton. Tapi presiden lalu memberi kesempatan untuk mengulang. Pelan tapi pasti petani kemudian mampu membacakan Pancasila walaupun terdapat kesalahn. Presiden memberikan kesempatan membacakan Pancasila hingga kali ketiga.

Respon presiden dengan bahasa rakyat tidak menunjukkan rasa kesal dan atau marah, justru presiden merasa simpatik dan memberikan arahan dengan memberikan kesempatan sampai tiga kali kepada petani membacakan Pancasila dengan baik dan benar.

Kuis ala presiden Jokowi bersama anak SD Jokowi di Tasikmalaya tahun 2017 mendengarkan nama-nama propinsi dan ibukota. Pada awalnya presiden hanya ingin mendengarkan tiga ibukota propinsi yang harus disebutkan oleh anak bernama Feri. "ibu kota Papua Jaya Pura, Ibukota Propinsi Jawa Barat Bandung, Maluku Utara Ternate, " mestinya sudah cukup namun presiden meminta satu lagi, "ibu Kota Sumatera Utara Palembang, tambah satu lagi kata presiden, 'ibukota sumatera Barat Padang'.

Bahasa dakwah dalam bidang politik yang disampaikan Joko Widodo merupakan bahasa lumrahnya politisi atau penguasa dalam menyampaikan kepentingan-kepentingan kekuasaan. Karena itu, Presiden Jokowi mempergunakan bahasa-bahasa propaganda, yang dalam istilah penulis propaganda 'bersahabat dan familiar dengan kalangan rakyat sipil.

Dalam membumisasikan program pembangunan sumber daya alam dan optimalisasi transportasi Trans Jawa misalnya, Presiden memberikan pernyataan-pernyataan yang visioner kepada masyarakat, akan pentingnya memperbaiki infrastuktur bahkan sampai ke luar pulau Jawa. 'Keadilan sosial bagi seluruh rakyat Indonesia' yang tertuang pada sila kelima menjadi dasar presiden menguraikan kebijakan-kebijakan tersebut.

Dalam menciptakan nawacita kesembilan, khususnya item 'menciptakan ruang-ruang dialog antarwarga'190 presiden sangat familiar dalam memberikan umpan balik dalam pidatopidatonya. Bahkan dalam setiap kesempatan bersama masyarakat presiden selalu memberikan kesempatan pada warga untuk melakukan tanya jawab secara langsung terkait kebijaka-kebijak baru. Tanya jawab sering bernuasa humor dan penuh kekeluargaan. Bahkan pada momentum pelayanan sertifikat tanah, presiden mendengarkan pernyataan jujur dari salah satu warga tentang kepemilikan tanah yang sudah di catat Badan Pertanahan Nasional.

Humor yang dilontarkan presiden merupakan cara tepat bagi masyarakat pecinta hiburan. Humor dalam sejarahnya menjadi bagian yang tidak dapat dipisahkan dari tradisi rakyat. Junaedi dalam Uwes menyebut, Humor merupakan bagian dari hiburan bisa menjadi teknik dalam berdakwah dan humor sendiri mudah diterima oleh masyarakat khususnya masyarakat Indonesia. Hal itu dikarenakan, jauh sebelum Indonesia merdeka, humor sendiri secara informal sudah menjadi bagian dari kesenian rakyat, misalnya ludruk, ketoprak, lenong, wayang kulit, wayang golek, dan sebagainya. ${ }^{191}$ Presiden Jokowi memiliki komunikasi yang dinamis dan luwes berbeda dengan presiden sebelumnya yang cenderung selalu formal dan kaku.

\footnotetext{
188 Dirgahayu, dida; sunarsi, risa. Kontribusi media televisi lokal dalam menyosialisasikan program revolusi mental. Jurnal penelitian komunikasi, [s.l.], v. 20, n. 2, dec. 2017.

${ }^{189}$ https://regional.kompas.com/read/2016/12/27/17112281/presiden.jokowi.hadiri.perayaan.natal.na sional.2016.di.minahasa

${ }^{190}$ Nawacita gagasan pemerintah telah dibumisasikan oleh Presiden secara optimal untuk perubahan Indonesia berdaulat secara politik dan mandiri dalam ekonomi serta berkepribadian dalam kebudayaan. ${ }^{191}$ Uwes Fatoni dan Sri Feni Hartati, Dakwah dan Humor; Sisipan Pesan Dakwah dalam Program siaran Humor Radio, Prosiding Konferensi Nasional Komunikasi, Vol. 01, No. 01, 2017, 932.
} 
Bahasa verbal dan non-verbal presiden Jokowi cukup mudah di pahami karena memilih kata-kata yang familiar dengan bahasa rakyat. Ideologi Pancasila menjadi bahasan yang rutin dipertanyakan kepada rakyat, karena Pancasila merupakan bagian yang penting ditengah arus globalisasi dan era milenial saat ini. Identitas budaya lokal dan budaya nasional dikawatirkan akan punah bila tidak dilakukan penguatan secara massif.

Upaya mempertahankan nasionalisme melalui kecintaan terhadap produksi dalam negeri pun tidak luput dari perhatian presiden. Dalam berbagai kesempatan presiden selalu memberikan hadiah 'sepeda' kepada rakyat. Sepeda menjadi hal yang unik dan berkesan bagi penerima karena mendapatkan hadiah dari kepala negara. Tentu masyarakat sipil sangat antusias menjadikan barang tersebut sebagai barang paling berharga.

Pada acara peringatan isra mi'raj di pondok pesantren API Tegalrejo Magelang, 14 Mei 2016, presiden jokowi menyempatkan dialog dengan santri. Muhammad Aska Fikri asal pekalongan yang melakukan tanya jawab dengan presiden menjawab pertanyaan yang tidak tepat. Pertanyaan tentang siapa saja nama menteri, justru di jawab oleh Aska Fikri dengan jawaban 'bu megawati', 'Ahok', 'Prabowo'. Jawaban disambut gelak tawa oleh para hadirin. Uniknya, presiden Jokowi tertawa dan tidak tampak wajah yang marah. Justru santri tersebut mendapatkan hadiah berupa sepeda dari presiden Jokowi. ${ }^{192}$ Pada video durasi 2 menit lebih itu Aska Fikri tampak sangat percaya diri dengan jawaban yang disampaikan. Bahkan sama sekali tidak ada unsur kesengajaan. Presiden Jokowi dengan bahasa Verbal merespon jawaban tanpa ada kemarahan sedikit pun, justru gelak tawa presiden tampaknya terhibur dengan jawaban santri.

Bahasa verbal yang disampaikan Presiden mudah dipahami karena menggunakan bahasa keseharian. Bahkan tidak canggung presiden terkadang menggunakan bahasa Jawa. Pada acara di Sleman 01 Agustus 2017, presiden berbahasa daerah dengan seorang siswa (Ihsanuddin Rasyid) dipanggil Udin. Udin sudah menerima program Imunisasi. Dalam Tanya jawab menjawab berbahasa Jawa di sela Bahasa Indonesia. "sudah diimunisasi?" Tanya Presiden. "Sampun" jawab Udin. Beberapa kata jawa yang sempat terucap adalah 'Boten", "Saestu Boten", Boten Ngelungelu"?, enggeh pun Maturnuwun", dan sterunya. Jenengan kerso sepeda nopo boten?, enggeh pun!". ${ }^{193}$

Bahasa verbal secara lisan yang disampaikan presiden Jokowi jelas untuk mengimbangi penggunaan bahasa jawa yang dipilih oleh Udin sebagai komunikannya. Logat kental jawa yang dilakukan Udin secara tepat direspon oleh Presiden dengan menggabungkan bahasa Indonesia dan Jawa. Bahasa Jawa sebagai bahasa yang dipergunakan oleh suku mayoritas merupakan identitas budaya lokal yang tidak lekang oleh zaman. Bahkan Presiden Jokowi, sebenarnya memang keturunan asli Jawa yang memiliki nama asli Mulyono. Sejak terpilik pada 2014, kepemimpinan Indonesia mendapatkan kepercayaan diri. Bahwa animo masyarakat terhadap kehadiran pemimpin baru yang arif dan bijaksana, dan sekaligus dapat membangun kultur baru dalam mengelola rakyat Indonesia. ${ }^{194}$ Disadari ataupun tidak pesan-pesan yang disampaikan presiden Jokowi sebagai kepala Negara, meminjam istilah M Sulthon dalam Farhan, merupakan bentuk dakwah struktural. ${ }^{195}$

Dalam konteks pengembangan kajian bahasa verbal atau non-verbal seorang presiden tetap menarik menjadi studi tokoh karena semua kebijakan yang disampaikan memiliki makna beragam. Apakah mudah diterima oleh rakyat sebagai penerima pesan, ataukah rakyat sebatas melaksanakan komunikasi semata tanpa merespon dengan melaksanakan kewajiban atas kebijakan pemerintah. Bahkan dalam kurun waktu tertentu Presiden Jokowi melakukan Tanya

192 Akun you tube pengunggah atas nama Presiden Joko Widodo, video di unggak pada 28 Mei 2016.

193 https://www.youtube.com/watch?v=4vWyb6QkVsk, video durasi 5 menit lebih diunggah oleh Jogja Archive.

194 Rachmanto, Rachmanto. "MENGEJAR PEMIMPIN IDEAL" Jurnal Kawistara: Jurnal Ilmiah Sosial dan Humaniora [Online], Vol. 4 No. 1 (21 April 2014), 105.

${ }^{195}$ Farhan, Farhan. "Bahasa Dakwah Struktural dan Kultural Da'i dalam Perspektif Dramaturgi", At-Turas: Jurnal Studi Keislaman, 1, 2 (2014). 
jawab melalui media sosial you tube. Syarat yang ditentukan bagi penanya antara usia 13-20 tahun. Durasi video yang dikirim maksimal 30 detik dengan satu pertanyaan. Pengiriman dilakukan mulai 18 Februari 2017 dan di tutup pada 25 Februari 2017.196

Jalinan komunikasi yang dilakukan Joko Widodo sangat unit menghadapi generasi era milenial. Partisipasinya dalam bermedia social tetap berjalan seperti halnya masyarakat sipil lainnya. Presiden Jokowi juga aktif di media sosial terutama facebook dan twitter. Bahkan dalam beberapa kali presiden juga menyempatkan diri ngevlog.

Pemerintah pusat sampai daerah propinsi dan kota/kabupaten menyelaraskan dengan kebijakan yang disampaikan presiden dan para menteri terkait. Karenanya, semua kebijakan terus dilakukan kajian dan evaluasi. Bahkan dalam tradisi bermedia social ala presiden Jokowi pun pada akhirnya dilakukan oleh beberapa kementerian. Contoh yang ditunjukkan oleh kepala Negara kepada aparatnya cukup berhasil dalam menarik perhatian masyarakat luas.

Pada kesempatan lain Presiden Jokowi memviralkan kuis-kuis sederhana, sebagai media memperkuat jalinan emosional dan silaturrahmi dengan rakyat. Misalnya kuis yang diunggah kali pertama pada 19 Maret 2017.

Kuis ini digelar Presiden di akun Facebook resmi, @Presiden Joko Widodo.Diunggah pertama kali pada 19 Marer 2017 lalu, Presiden menulis, "Kali ini, pertanyaannya bukan tentang nama-nama ikan, pulau, atau provinsi. Tapi hadiahnya sama, sepeda. Ayo, siapa yang mau dapat sepeda, jawab pertanyaan ini ya!" Pertanyaannya "seperti apakah negara Indonesia yang maju menurut kamu?".197

Kuis yang direncakan sampai 24 Maret 2017 tersebut, hingga Senin pukul 10.48 WIB, unggahan kuis \#SepedaJokowi itu sudah dikomentari sebanyak 80.369 kali. Adapun, unggahan itu juga sudah dibagikan sebanyak 11.102 kali.

\section{Pemerintah sebagai Inovator dan Inisiator}

Bahasa dakwah yang dipahami dari sumber hukum Islam menjadi tolok ukur katagorisasi seorang pendakwah menyesuaikan objek dakwah. Era milenial tidak lagi menempatkan objek dakwah yang cukup berbeda satu dengan lainnya. Justru antar subjek dan objek dakwah baik melalui perspektif dakwah kultural maupun struktural kedua unsur dakwah tersebut berada dalam kondisi yang sangat dinamis mengikuti pola media dakwah yang dipergunakan.

Pemerintah melalui inisiator Presiden Joko Widodo menyampaikan pesan verbal dan nonverbal (bahasa Dakwah) begitu familiar dan mudah akrab dengan rakyat. Respon yang diberikan penerima pesan sungguh sangat menakjubkan, terlebih diperkuat dengan simbol reward (hadiah) yang sengaja diberikan oleh presiden sebagai kesan dan kenangan prestisius bagi penerima dengan jalan bijak. Dalam konteks ilmu komunikasi hal tersebut sama halnya dengan perkataan retoris, sinonim dengan qaulan ma'rufa ${ }^{198}$ dan atau selalu terjalin interakasi antar unsur pemberi pesan dengan penerima pesan (Stimulus-Respon). Sama halnya dengan bahasa dakwah waulan maisura, dengan adanya komunikasi dua arah yang berkesinambungan antara komunikator dan komunikan.

Penampilan non-verbal yang ditampakkan presiden pun terkadang cukup unik. Tidak terlihat menakutkan dan atau 'direndahkan' oleh masyarakat, lebih tepat tetap menjaga kewibawaan sebagai kepala Negara sekalipun tidak menampilkan diri dengan performance seorang presiden yang harus rapih dengan jas, melainkan cukup berpakain rapi. Dikala kegiatan keagamaan seperti biasa menggunakan symbol agama (kopiah) dst. Dalam kegiatan peresmian dan atau peringatan mempergunakan pakaian rapih dan sopan.

Dalam menjalin komunikasi dengan audien yang ditindaklanjuti komunikasi antar person didepan khalayak, presiden Jokowi lebih memilih bahasa lembut (qaulan layyina) dan bahasa

\footnotetext{
196 https://www.tribunnews.com/nasional/2017/02/19/presiden-jokowi-ajak-warga-bertanya-lewatmedsos-ini-syaratnya

197 Fabian Januarius Kuwado, Jokowi bikin kuis di facebook hadiahnya 10 Sepeda dalam https://nasional.kompas.com/read/2017/03/20/11091921

198 Deddy Mulyana, Ilmu Komunikasi Suatu Pengantar (Bandung: Rosdakarya, 2005), 134-135.
} 
mulia (qaulan karima). Pilihan kata penghormatan di tujukan utamanya kepada komunikan yang dari kalangan lansia (orang tua) dan anak-anak. Apapun yang menjadi kesalahan dalam Tanya jawab bersama presiden Jokowi, komunikan tidak serta merta ditegur secara kasar. Justru presiden Jokowi menginovasi kata-kata yang disampaikan senyampang tidak menyakiti komunikan. Sikap presiden dengan memilih kata-kata penghormatan kepada komunikan dari sipil merupakan keteladanan seorang pemimpin yang terbuka gamblang kepada rakyatnya atas semua kebijakan yang diputuskan.

Semua kebijakan baik politik, pendidikan, ekonomi, budaya dan seterusnya itu oleh presiden dijadikan sebagai materi ringan yang menarik hati masyarakat untuk terus mengikuti pesan-pesan presiden. Dengan demikian, perintah dan larangan yang disampaikan presiden kepada masyarakat sipil terkait kebijakan yang telah diambil pemerintah mulai pusat hingga ke daerah langsung disaksikan semua lapisan masyarakat.

Inisatif presiden dalam berinteraksi dan berkomunikasi secara gamblang hingga menerima saran dan kritikan tersebut, tidak bisa dilakukan oleh kepala Negara pada umumnya. Namun, keberanian presiden Jokowi dengan kepercayaan diri yang tinggi, mampu menyampaikan pesanpesan pemerintah dengan gaya bahasa yang humoris, tradisionalis dan nasionalis. Karena itu, pertanyaan yang sering terlontar dari presiden Jokowi adalah tentang "Pancasila". Lima dasar sebagai ideology Negara yang menjadi kewajiban semua warga Negara Indonesia yang baik untuk menghafal, memahami, menghayati dan mengamalkan kandungannya.

Bagi Jokowi, Pancasila adalah Benteng menghadapi perkembangan ideology lain yang akan terus berkembang dan mencoba mempengaruhi ideologi Negara. "Setiap tantangan yang mengganggu persatuan bangsa dan mengganggu Pancasila, harus menambah kedewasaan kita. Semakin dewasa dalam berdemokrasi. Dan semakin strategis dalam melangkah untuk kemajuan bangsa. Dan semakin dewasa dalam menjaga persatuan dan ketenteraman kita, " tegas Kepala Negara. ${ }^{199}$

Bahasa dakwah pemerintah selama masa kepala presiden Jokowi terkesan ramah namun tegas. Ramah dengan gaya bahasa khas yang humoris meskipun ditujukan untuk mengevaluasi kinerja para menterinya. Dan bahasa dakwah presiden selalu memberikan inisatif kepada para pejabat dan kepala daerah dalam memberikan pelayanan dan pengabdian kepada masyarakat. Kepala daerah bahkan tidak segan-segan mencontoh kepala Negara dengan cara 'Blusukan' tanpa risih ditengah kerumunan pasar bertemu dan berinteraksi dengan pedagang dan rakyat sipil.

Komunikasi pembangunan yang baik dari pemerintah ke masyarakat dapat meningkatkan hadirnya negara di masyarakat. Semua kebijakan pemerintah harus terkomunikasikan secara lengkap kepada masyarakat. ${ }^{200}$

Pemerintah pusat hingga daerah sangat memahami maksud dari kepala Negara dalam hal mempercepat pelayanan di era modern. Bahkan dalam program pengentasan kemiskinan dan meningkatkan keadilan sosial bagi seluruh rakyat Indonesia, presiden Jokowi tidak kenal lelah mengagendakan hadir di daerah-daerah terpencil sekalipun. Dalam setiap unggahan pidato yang di upload di media sosial, penulis belum mendapati adanya agenda pemerintah yang tidak mendapatkan perhatian optimal. Justru program-program yang dibahas dan diuraikan secara sederhana melalui dialog dan Tanya jawab, tampaknya menjadikan rakyat dan netizen semakin menyatu dengan kepala Negaranya.

\section{E. Kesimpulan}

Pemerintahan Jokowi memiliki gaya bahasa dakwah yang sinergis satu dengan lainnya. Aspek kehidupan masyarakat dipersatukan dalam bahasa retorika pemerintah yang nyaman; dengan bahasa humor tinggi, mengusung tradisionalitas (budaya lokal), dan tetap

199 https://kominfo.go.id/content/detail/19067/presiden-pancasila-jadi-benteng-hadapi-bahayaideologi-lain/0/berita

200 Jaya, Pajar Hatma Indra. "Distorsi Komunikasi Pembangunan Pemerintahan Presiden Jokowi di Media Sosial." Jurnal Ilmu Komunikasi Vol. 14, No. 2, 2017, 273. 
mempersatukan persepsi dengan ideology yang satu. Sebagai ideologi yang diterima semua kalangan. Bahwa Negara Kesatuan Republik Indonesia adalah Harga Mati yang perlu dipertahankan. Dengan upaya optimal mengikuti trend masyarakat kekinian, presiden memberikan contoh atau keteladanan, dan atau mejadi inisiator dan innovator selaras dengan kecenderungan rakyat era milenial.

\section{Referensi}

Anwar. 1984. Fungi dan Peranan Bahasa sebuah Pengantar. Yogyakarta: Gajdah Mada University Press.

Assidik, Gallant Karunia dan Santoso, B. Wahyudi Joko. “Citra Publik Presiden Republik Indonesia Pada Pemberitaan Harian Suara Merdeka Tabloid Tempo dan Harian Republika: Analisis Wacana Kritis Model Norman Fairclough", Seloka: Jurnal Pendidikan Bahasa dan Sastra Indonesia, 5 (2) 2016.

Dirgahayu, Dida, and Sunarsi, Risa. "Kontribusi Media Televisi Lokal dalam Menyosialisasikan Program Revolusi Mental" Jurnal Penelitian Komunikasi [Online], Volume 20 Number 2, 18 December 2017.

Dirgahayu, Dida; Sunarsi, risa. "Kontribusi Media Televisi Lokal dalam Menyosialisasikan Program Revolusi Mental”. Jurnal Penelitian Komunikasi, [s.l.], Vol. 20, No. 2, Dec. 2017.

Eriyanto, 2014. Analisis Framing Konstruksi, Ideologi, dan Politik Media. Yogyakarta: LKiS.

Farhan, Farhan. "Bahasa dakwah struktural dan kultural da'i dalam perspektif dramaturgi." atturas: Jurnal Studi Keislaman 1.2 (2014).

Fatoni, Uwes dan Hartati, Sri Feni. "Dakwah dan Humor; Sisipan Pesan Dakwah dalam Program siaran Humor Radio", Prosiding Konferensi Nasional Komunikasi, Vol. 01, No. 01, 2017, 932.

Indriyanto, Bambang. "Mengkaji Revolusi Mental dalam Konteks Pendidikan" Jurnal Pendidikan dan Kebudayaan [Online], Volume 20 Number 4 (18 December 2014).

Muhtadi, Asep Saeful. Komunikasi Politik Indonesia Dinamika Islam Politik Pasca Orde Baru. Bandung: PT Remaja Rosdakarya, 2008.

Nimmo, Dan D. Komunikasi Politik Komunikator, Pesan dan Media, terj. Tjun Surjaman. Bandung: PT. Remaja Rosdakarya, 2004.

Rachmanto, Rachmanto. "Mengejar Pemimpin Ideal", Jurnal Kawistara: Jurnal Ilmiah Sosial dan Humaniora [Online], Volume 4 Number 1 (21 April 2014), 105.

Wulandari, Theresia. "Pemerintahan Jokowi-Jusuf Kalla Menurut Kacamata 5 Media Massa di Indonesia" Jurnal ASPIKOM [Online], Volume 3 Number 1 (18 July 2016). 